$\begin{array}{rr}\text { JURNAL } & \\ \text { FIT(1)PATOLOGI } & \text { Volume 10, Nomor 6, Desember } 2014 \\ \text { I N D O N E S IA } & \text { Halaman } 188-194 \\ \text { ISSN: } 0215-7950 & \text { DOI: } 10.14692 / \text { jfi. } 10.6 .188\end{array}$

\title{
Integrasi Teknik Invigorasi Benih dengan Rizobakteri untuk Pengendalian Penyakit dan Peningkatan Hasil Tomat
}

\author{
Integration of Seed Invigoration with Rhizobacteria to \\ Control Disease and Improve Yield of Tomato
}

\author{
Gusti Ayu Kade Sutariati, Abdul Madiki, Andi Khaeruni* \\ Universitas Halu Oleo, Kendari 93232
}

\begin{abstract}
ABSTRAK
Pengujian lapangan dilakukan untuk mengetahui perkembangan penyakit layu fusarium dan pertumbuhan tanaman tomat setelah perlakuan benih dengan teknik invigorasi yang dintegrasikan dengan rizobakteri. Perlakuan benih terdiri atas invigorasi dengan rizobakteri tunggal atau campuran, matriconditioning arang sekam padi atau serbuk, matriconditioning arang sekam padi atau serbuk yang diintegrasikan dengan rizobakteri tunggal atau campuran, hidrasi benih, dan fungisida. Hasil penelitian menunjukkan bahwa perlakuan yang paling efektif ialah integrasi matriconditioning arang sekam padi pada benih dengan rizobakteri Bacillus polymixa BG25. Perlakuan tersebut mampu meningkatkan jumlah dan bobot buah, berturut-turut $40 \%$ dan $166 \%$, serta menekan perkembangan penyakit layu fusarium sebesar $70 \%$. Oleh karena itu perlakuan tersebut dapat direkomendasikan sebagai perlakuan pra-tanam pada benih tomat untuk meningkatkan hasil panen dan mengendalikan penyakit layu fusarium di lapangan.
\end{abstract}

Kata kunci: arang sekam padi, Bacillus polymixa, layu fusarium

\begin{abstract}
The effects of pre-planted seed invigoration treatment integrated with rhizobacteria were studied in an attempt to control fusarium wilt disease and to improve yield of tomato in the field. Seed treatments consisted of seed invigoration with single or mixture rhizobacteria, burned rice husk or sawdust seed matriconditioning, integrated seed matriconditioning with single or mixture rhizobacteria, seed hydration, and fungicide seed treatment. The result showed that the most effective treatment was the integration of rice hull charcoal seed matriconditioning with Bacillus polymixa BG25. The seed treatment increased total fruit and fruit weight by $40 \%$ and $166 \%$, respectively. The treatment was also effective in suppressing disease incidence by $70 \%$. Based on this experiment, rhizobacteria B. polymixa $\mathrm{BG} 25$ integrated with rice hull charcoal seed matriconditioning can be recommended as biocontrol agents in improving yield and controlling fusarium wilt disease of tomato.
\end{abstract}

Key words: Bacillus polymixa, fusarium wilt disease, rice hull charcoal

\section{PENDAHULUAN}

Tomat merupakan komoditas sayuran penting di Indonesia, karena tomat sudah menjadi kebutuhan pokok masyarakat sehari- hari yang bernilai ekonomis tinggi. Kebutuhan masyarakat akan tomat di Sulawesi Tenggara belum diimbangi dengan produktivitas yang memadai. Produktivitas tomat di Sulawesi Tenggara masih sangat rendah yaitu,

*Alamat penulis korespondensi: Jurusan Agroteknologi Fakultas Pertanian Universitas Halu Oleo, Kampus Bumi Tridharma, Jalan HEA Mohodompit Anduonohu, Kendari 93232

Tel: 0401-3193596, Faks: 0401-3193596, Surel: akhaeruni@yahoo.com 
5 ton ha $^{-1}$, sementara rata-rata produktivitas nasional mencapai 20 ton ha $^{-1}$ (BPS 2004).

Keterbatasan benih unggul bermutu di lapangan dan insidensi penyakit layu masih merupakan kendala utama dalam peningkatan produktivitas tanaman tomat, sehingga masih memerlukan pengkajian lebih mendalam dan berkelanjutan untuk mendapatkan solusi pemecahan yang lebih baik. Gangguan penyakit menimbulkan efek yang jauh lebih luas jika patogen terbawa benih karena sumber penyebaran patogen sudah ada sejak awal pertumbuhan tanaman di lapangan. Oleh karena itu, benih harus dipersiapkan sebelum tanam dengan memberikan perlakuan benih yang dapat meningkatkan vigor benih, sekaligus mengendalikan penyakit sehingga produktivitas tanaman meningkat.

Perlakuan benih dengan mikroorganisme yang berasosiasi secara alami dan sinergis dengan tanaman inang merupakan salah satu solusi untuk meningkatkan produktivitas dan ketahanan tanaman terhadap penyakit. Teknik pengendalian ini semakin populer karena meningkatnya kepedulian masyarakat terhadap permasalahan keamanan hayati dan kesehatan lingkungan sehubungan dengan fitotoksisitas akibat penggunaan pestisida sintetik yang berlebihan. Rizobakteri pemacu pertumbuhan tanaman telah banyak dikembangkan dan dilaporkan efektif untuk mengendalikan berbagai penyakit tanaman. Rizobakteri dari kelompok Serratia sp J2, Pseudomonas fluorescens J3 dan Bacillus sp. BB11 memiliki kemampuan menghambat perkembangan penyakit layu bakteri yang disebabkan oleh Ralstonia solanacearum sebesar 6674\% (Guo et al. 2004). Aplikasi formulasi campuran rizobakteri $B$. subtilis ST21b, $B$. cereus ST21e, dan Serratia sp. SS29a efektif mengendalikan penyakit layu fusarium pada tanaman tomat (Khaeruni et. al. 2013) dan melindungi tanaman kedelai dari infeksi $R$. solani (Khaeruni et al. 2014). Penggunaan rizobakteri sebagai agens pengendalian hayati selain mempunyai potensi untuk melindungi tanaman selama siklus hidupnya, juga mampu menghasilkan hormon tumbuh, memfiksasi nitrogen, melarutkan fosfat sehingga memberi manfaat ganda bagi tanaman. Sejumlah isolat bakteri dari rizosfer tanaman cabai telah diteliti kemampuannya sebagai agens hayati dan pemacu pertumbuhan tanaman. Tiga isolat bakteri, yaitu B. polymixa BG25, $S$. liquefaciens SG01, dan $P$. fluorescens PG01 memiliki kemampuan meningkatkan vigor benih dan pertumbuhan tanaman cabai (Sutariati et al. 2006; Sutariati dan Wahab 2011), dan tanaman sorgum (Sutariati dan Khaeruni 2013) .

Penelitian ini bertujuan mendapatkan metode perlakuan benih melalui penggunaan teknik invigorasi benih dengan penambahan rizobakteri yang berperan sebagai biofertilizer dan biopestisida untuk mengendalikan penyakit dan meningkatkan hasil tanaman tomat.

\section{BAHAN DAN METODE}

\section{Perbanyakan Isolat Rizobakteri}

Isolat rizobakteri $B$. polymixa $\mathrm{BG} 25$ dan $S$. liquefaciens SG01 diperbanyak pada medium Tryptone soya agar (TSA), sedangkan P. fluorescens PG01 pada medium King's B. Biakan murni yang berumur 48 jam disuspensikan dalam akuades steril sampai mencapai kerapatan populasi $10^{9} \mathrm{cfu} \mathrm{mL}^{-1}$ (Sutariati et al. 2010).

\section{Perlakuan Teknik Invigorasi dengan \\ Penambahan Rizobakteri pada Benih}

Percobaan lapangan disusun menggunakan rancangan acak kelompok dengan 18 perlakuan benih yaitu, kontrol; hidrasi; fungisida; matriconditioning dengan serbuk arang sekam (Matrik MA); matriconditioning dengan serbuk gergaji (Matrik SG); Biopriming dengan B. polymixa BG25 (BG25); Biopriming dengan $P$. fluorescens PG01 (PG01); Biopriming dengan S. liquefaciens SG01 (SG01); Biopriming BG25 + PG01; Biopriming BG25 + SG01; Biopriming PG01 + SG01; Biopriming BG25 + PG01 + SG01; Biomatrik MA + BG25; Biomatrik SG + BG25; Biomatrik MA + PG01; Biomatrik SG + PG01; Biomatrik MA + SG01; Biomatrik $\mathrm{SG}+\mathrm{SG01}$. Setiap perlakuan diulang $3 \mathrm{kali}$ sehingga terdapat 54 unit percobaan. 
Benih tomat terlebih dahulu didisinfeksi dengan natrium hipoklorit 5\% selama 10 menit, dicuci 3 kali dengan air steril, dan dikeringanginkan dalam laminar air flow cabinet selama 1 jam. Perlakuan benih diuji pada suhu kamar mengikuti metode yang telah dilakukan sebelumnya (Sutariati dan Khaeruni 2013).

Benih tomat yang telah diberi perlakuan disemai dalam bak persemaian. Setelah berumur 4 minggu, bibit dipindahtanam dengan jarak tanam $50 \mathrm{~cm} \times 60 \mathrm{~cm}$ dalam petakan-petakan percobaan seluas $5 \mathrm{~m}^{2}$. Pemupukan tanaman dengan $\mathrm{N}\left(100 \mathrm{~kg} \mathrm{ha}^{-1}\right)$ dilakukan 2 kali ( $1 / 3$ dosis pada saat tanam dan $2 / 3$ dosis saat tanaman berumur 4 minggu), sedangkan $\mathrm{P}\left(150 \mathrm{~kg} \mathrm{ha}^{-1}\right)$ dan $\mathrm{K}_{2} \mathrm{O}(100 \mathrm{~kg}$ $\mathrm{ha}^{-1}$ ) diberikan bersamaan waktu tanam.

Pengamatan pertumbuhan tanaman tomat menggunakan peubah tinggi tanaman dan jumlah cabang primer. Jumlah buah total, bobot buah total dan jumlah benih per buah diukur sebagai peubah hasil. Pengamatan terhadap kemampuan rizobakteri mengendalikan penyakit dilakukan dengan mengamati insidensi penyakit layu fusarium yang terjadi secara alami dengan rumus:

$$
\mathrm{IP}=\frac{\mathrm{Y}}{\mathrm{N}} \times 100 \% \text {, dengan }
$$

IP, insidensi penyakit; Y, jumlah tanaman terserang; $\mathrm{N}$, jumlah tanaman yang diamati.

Semua data yang diperoleh dianalisis menggunakan analisis keragaman pada taraf kepercayaan 95\%. Uji nilai tengah dilakukan dengan uji Duncan.

\section{HASIL}

\section{Tinggi Tanaman}

Saat tanaman berumur 4 minggu setelah tanam (MST), belum tampak secara nyata perbedaan pengaruh perlakuan invigorasi benih atau integrasinya dengan rizobakteri dibandingkan dengan kontrol, kecuali pada benih yang mendapat perlakuan fungisida tampak adanya penghambatan pertumbuhan yang berbeda nyata dengan kontrol dan perlakuan lainnya. Namun demikian, di antara 18 perlakuan benih yang diuji, rizobakteri
B. polymixa BG25 secara mandiri dan yang diintegrasikan dengan teknik invigorasi menggunakan matriconditioning serbuk arang sekam (Biomatrik serbuk arang sekam + BG25) dan rizobakteri P. fluorescens PG01 yang diintegrasikan dengan teknik invigorasi menggunakan matriconditioning serbuk gergaji (Biomatrik serbuk gergaji + PG01) memberikan tinggi tanaman yang baik walaupun tidak berbeda nyata dengan kontrol dan perlakuan benih lainnya (Tabel 1).

\section{Jumlah Cabang Primer}

Aplikasi perlakuan benih menggunakan rizobakteri atau rizobakteri yang diintegrasikan dengan teknik invigorasi berpengaruh nyata terhadap jumlah cabang primer tanaman tomat. Pada pengamatan 4 MST di antara 18 perlakuan benih yang diuji, aplikasi B. polymixa BG25 yang dikombinasikan dengan $P$. fluorescens PG01 (biopriming), memberikan jumlah cabang primer lebih banyak dibandingkan dengan perlakuan lainnya. Jumlah cabang primer terendah diperoleh pada kontrol dan berbeda nyata dengan perlakuan lainnya. Pada pengamatan 8 MST, perlakuan benih yang mampu memberikan jumlah cabang primer terbanyak ialah $B$. polymixa BG25 yang diintegrasikan dengan matrik serbuk arang sekam. Perlakuan ini berbeda nyata dengan kontrol, peningkatan jumlah cabang primernya mencapai 48\% (Tabel 2).

\section{Jumlah Buah Total, Bobot Buah Total, dan Jumlah Benih per Buah}

Perlakuan benih menggunakan teknik invigorasi yang diintegrasikan dengan rizobakteri secara nyata meningkatkan hasil cabai dibandingkan dengan kontrol (Tabel 3). Perlakuan benih dengan mengintegrasikan $B$. polymixa BG25 dan matriconditioning serbuk arang sekam ternyata mampu meningkatkan jumlah buah total tomat sampai $40 \%$ dibandingkan dengan kontrol. Integrasi $B$. polymixa BG25 dengan matriconditioning serbuk arang sekam juga mampu meningkatkan bobot buah total per tanaman. Bobot buah terendah diperoleh pada kontrol dan berbeda dengan perlakuan lainnya. Peningkatan bobot 
Tabel 1 Tinggi tanaman tomat pada perlakuan teknik invigorasi benih yang diintegrasikan dengan rizobakteri

\begin{tabular}{lcc}
\hline \multirow{2}{*}{ Perlakuan benih } & \multicolumn{2}{c}{ Tinggi tanaman $(\mathrm{cm})$} \\
\cline { 2 - 3 } & $4 \mathrm{MST}$ & $8 \mathrm{MST}$ \\
\hline Kontrol & $33.92 \mathrm{ab}$ & $82.53 \mathrm{fg}$ \\
Hidrasi & $33.78 \mathrm{ab}$ & $90.27 \mathrm{de}$ \\
Fungisida & $32.21 \mathrm{~b}$ & $81.38 \mathrm{~g}$ \\
Matrik Serbuk arang sekam (MA) & $35.38 \mathrm{ab}$ & $88.79 \mathrm{~d}-\mathrm{f}$ \\
Matrik Serbuk gergaji (MG) & $35.18 \mathrm{ab}$ & $87.28 \mathrm{e}-\mathrm{g}$ \\
Biopriming BG25 & $39.61 \mathrm{a}$ & $100.68 \mathrm{a}-\mathrm{c}$ \\
Biopriming PG01 & $37.05 \mathrm{ab}$ & $101.02 \mathrm{a}-\mathrm{c}$ \\
Biopriming SG01 & $36.49 \mathrm{ab}$ & $104.31 \mathrm{ab}$ \\
Biopriming BG25 + PG01 & $37.42 \mathrm{ab}$ & $100.56 \mathrm{a}-\mathrm{c}$ \\
Biopriming BG25 + SG01 & $38.89 \mathrm{ab}$ & $103.35 \mathrm{ab}$ \\
Biopriming PG01 + SG01 & $37.76 \mathrm{ab}$ & $94.95 \mathrm{~cd}$ \\
Biopriming BG25 + PG01 + SG01 & $39.38 \mathrm{ab}$ & $99.43 \mathrm{bc}$ \\
Biomatrik BG25 + MA & $40.49 \mathrm{a}$ & $106.72 \mathrm{ab}$ \\
Biomatrik PG01 + MA & $36.39 \mathrm{ab}$ & $100.06 \mathrm{bc}$ \\
Biomatrik SG01 + MA & $36.42 \mathrm{ab}$ & $101.55 \mathrm{a}-\mathrm{c}$ \\
Biomatrik BG25 + MG & $36.75 \mathrm{ab}$ & $104.13 \mathrm{ab}$ \\
Biomatrik PG01 + MG & $40.67 \mathrm{a}$ & $107.99 \mathrm{a}$ \\
Biomatrik SG01 + MG & $37.25 \mathrm{ab}$ & $99.47 \mathrm{bc}$ \\
\hline Ang-ang & &
\end{tabular}

Angka-angka yang diikuti oleh huruf yang sama menunjukkan tidak berbeda nyata pada taraf uji DMRT $\alpha 5 \%$. MST, minggu setelah tanam; BG25, B. polymixa BG25; PG01, P. fluorescens PG01; SG01, S. liquefaciens SG01; MA, matriconditioning dengan serbuk arang sekam; MG, matriconditioning dengan serbuk gergaji.

Tabel 2 Jumlah cabang primer pada perlakuan teknik invigorasi benih yang diintegrasikan dengan rizobakteri

\begin{tabular}{lll}
\hline \multirow{2}{*}{ Perlakuan benih } & \multicolumn{2}{c}{ Jumlah cabang primer } \\
\cline { 2 - 3 } Kontrol & $4 \mathrm{MST}$ & $8 \mathrm{MST}$ \\
Hidrasi & $2.83 \mathrm{~d}$ & $5.00 \mathrm{~g}$ \\
Fungisida & $3.58 \mathrm{dc}$ & $5.83 \mathrm{fg}$ \\
Matrik Serbuk arang sekam (MA) & $3.92 \mathrm{~b}-\mathrm{d}$ & $5.92 \mathrm{fg}$ \\
Matrik Serbuk gergaji (MG) & $3.75 \mathrm{~b}-\mathrm{d}$ & $6.33 \mathrm{ef}$ \\
Biopriming BG25 & $4.33 \mathrm{a}-\mathrm{c}$ & $6.67 \mathrm{~d}-\mathrm{f}$ \\
Biopriming PG01 & $4.75 \mathrm{a}-\mathrm{c}$ & $7.33 \mathrm{de}$ \\
Biopriming SG01 & $4.33 \mathrm{a}-\mathrm{c}$ & $6.92 \mathrm{~d}-\mathrm{f}$ \\
Biopriming BG25 + PG01 & $4.58 \mathrm{a}-\mathrm{c}$ & $7.25 \mathrm{de}$ \\
Biopriming BG25 + SG01 & $3.92 \mathrm{~b}-\mathrm{d}$ & $7.17 \mathrm{de}$ \\
Biopriming PG01 + SG01 & $4.75 \mathrm{a}-\mathrm{c}$ & $7.92 \mathrm{~b}-\mathrm{d}$ \\
Biopriming BG25 + PG01 + SG01 & $5.33 \mathrm{a}$ & $8.92 \mathrm{ab}$ \\
Biomatrik BG25 + MA & $4.67 \mathrm{a}-\mathrm{c}$ & $8.67 \mathrm{a}-\mathrm{c}$ \\
Biomatrik PG01 + MA & $4.83 \mathrm{a}-\mathrm{c}$ & $9.33 \mathrm{a}$ \\
Biomatrik SG01 + MA & $4.17 \mathrm{a}-\mathrm{c}$ & $7.58 \mathrm{c}-\mathrm{e}$ \\
Biomatrik BG25 + MG & $4.33 \mathrm{a}-\mathrm{c}$ & $7.92 \mathrm{~b}-\mathrm{d}$ \\
Biomatrik PG01 + MG & $4.17 \mathrm{a}-\mathrm{c}$ & $7.42 \mathrm{c}-\mathrm{e}$ \\
Biomatrik SG01 + MG & $4.92 \mathrm{ab}$ & $8.67 \mathrm{a}-\mathrm{c}$ \\
\hline Ang-anga yang & $4.58 \mathrm{a}-\mathrm{c}$ & $7.75 \mathrm{~b}-\mathrm{d}$ \\
\hline
\end{tabular}

Angka-angka yang diikuti oleh huruf yang sama menunjukkan tidak berbeda nyata pada taraf uji DMRT $\alpha 5 \%$. MST, minggu setelah tanam; BG25, B. polymixa BG25; PG01, P. fluorescens PG01; SG01, S. liquefaciens SG01; $\mathrm{MA}$, matriconditioning dengan serbuk arang sekam; $\mathrm{MG}$, matriconditioning dengan serbuk gergaji. 
buah total mencapai $166 \%$ dibandingkan dengan kontrol.

Aplikasi perlakuan benih juga berpengaruh secara nyata terhadap jumlah benih per buah. $B$. polymixa $\mathrm{BG} 25$ yang diintegrasikan dengan matriconditioning serbuk arang sekam atau $P$. fluorescens PG01 yang diintegrasikan dengan matriconditioning serbuk gergaji mampu meningkatkan jumlah benih per buah dan berbeda nyata dibandingkan dengan kontrol dan perlakuan lainnya. Peningkatan jumlah benih per buah mencapai $83-85 \%$ dibandingkan dengan kontrol (Tabel 3).

\section{Insidensi Penyakit}

Terjadi penurunan persentase insidensi penyakit layu fusarium yang nyata pada benih yang mendapat perlakuan rizobakteri atau rizobakteri yang diintegrasikan dengan teknik invigorasi benih (Tabel 4). Ketiga rizobakteri yang digunakan $(S$. liquefaciens SG01, $B$. polymixa BG25, dan P. fluorescens PG01) baik secara mandiri maupun kombinasi dengan teknik invigorasi benih (matriconditioning dengan serbuk arang sekam dan serbuk gergaji) secara nyata mampu menurunkan insidensi penyakit dibandingkan dengan kontrol.

Penurunan insidensi penyakit berkisar antara 87-96\% dibandingkan dengan kontrol. Hasil penelitian ini juga menunjukkan bahwa teknik invigorasi benih yang diintegrasikan dengan rizobakteri melalui aplikasi pada benih ternyata lebih efektif dibandingkan dengan perlakuan benih menggunakan fungisida (Tabel 4).

\section{PEMBAHASAN}

Hasil penelitian menunjukkan bahwa berdasarkan pengukuran peubah pertumbuhan dan produksi, $B$. polymixa BG25 yang diintegrasikan dengan teknik invigorasi menggunakan matriconditioning serbuk arang sekam dan P. fluorescens PG01 yang diintegrasikan dengan teknik invigorasi menggunakan matriconditioning serbuk gergaji memberikan hasil

Tabel 3 Jumlah buah total, bobot buah total, dan jumlah benih per buah pada perlakuan teknik invigorasi benih yang diintegrasikan dengan rizobakteri

\begin{tabular}{lccr}
\hline \multirow{2}{*}{ Perlakuan benih } & \multicolumn{3}{c}{ Hasil tanaman tomat } \\
\cline { 2 - 4 } & JBT & \multicolumn{1}{c}{ BBT $(\mathrm{g})$} & \multicolumn{1}{c}{ JBN } \\
\hline Kontrol & $21.08 \mathrm{e}$ & $1007.63 \mathrm{f}$ & $89.92 \mathrm{~h}$ \\
Hidrasi & $25.75 \mathrm{~d}$ & $1155.42 \mathrm{ef}$ & $112.75 \mathrm{f}$ \\
Fungisida & $26.58 \mathrm{~b}-\mathrm{d}$ & $1315.47 \mathrm{de}$ & $98.33 \mathrm{~g}$ \\
Matrik Serbuk arang sekam (MA) & $28.67 \mathrm{a}-\mathrm{d}$ & $1511.50 \mathrm{~d}$ & $111.00 \mathrm{f}$ \\
Matrik Serbuk gergaji (MG) & $28.92 \mathrm{a}-\mathrm{d}$ & $2076.75 \mathrm{c}$ & $114.50 \mathrm{f}$ \\
Biopriming BG25 & $28.58 \mathrm{a}-\mathrm{d}$ & $2520.92 \mathrm{ab}$ & $126.25 \mathrm{c}$ \\
Biopriming PG01 & $26.08 \mathrm{~cd}$ & $2259.83 \mathrm{~b}$ & $117.33 \mathrm{ef}$ \\
Biopriming SG01 & $28.00 \mathrm{a}-\mathrm{d}$ & $2492.33 \mathrm{ab}$ & $127.50 \mathrm{~cd}$ \\
Biopriming BG25 + PG01 & $27.83 \mathrm{a}-\mathrm{d}$ & $2437.33 \mathrm{ab}$ & $122.67 \mathrm{de}$ \\
Biopriming BG25 + SG01 & $28.25 \mathrm{a}-\mathrm{d}$ & $2546.00 \mathrm{ab}$ & $127.92 \mathrm{~cd}$ \\
Biopriming PG01 + SG01 & $29.42 \mathrm{ab}$ & $2471.08 \mathrm{ab}$ & $138.25 \mathrm{~b}$ \\
Biopriming BG25 + PG01 SG01 & $28.67 \mathrm{a}-\mathrm{d}$ & $2423.92 \mathrm{ab}$ & $137.83 \mathrm{~b}$ \\
Biomatrik BG25 + MA & $29.83 \mathrm{a}$ & $2681.00 \mathrm{a}$ & $166.67 \mathrm{a}$ \\
Biomatrik PG01 + MA & $26.58 \mathrm{~b}-\mathrm{d}$ & $2320.83 \mathrm{bc}$ & $130.25 \mathrm{~b}-\mathrm{d}$ \\
Biomatrik SG01 + MA & $29.08 \mathrm{a}-\mathrm{c}$ & $2501.33 \mathrm{ab}$ & $134.00 \mathrm{bc}$ \\
Biomatrik BG25 + MG & $26.50 \mathrm{~b}-\mathrm{d}$ & $2366.42 \mathrm{a}-\mathrm{c}$ & $136.58 \mathrm{~b}$ \\
Biomatrik PG01 + MG & $28.83 \mathrm{a}-\mathrm{d}$ & $2504.17 \mathrm{ab}$ & $163.17 \mathrm{a}$ \\
Biomatrik SG01 + MG & $26.42 \mathrm{~b}-\mathrm{d}$ & $2322.08 \mathrm{bc}$ & $138.00 \mathrm{~b}$ \\
\hline A & &
\end{tabular}

Angka-angka yang diikuti oleh huruf yang sama menunjukkan tidak berbeda nyata pada taraf uji DMRT $\alpha$ 5\%. JBT, jumlah buah total; BBT, bobot buah total; JBN, jumlah benih per buah;

BG25, B. polymixa BG25; PG01, P. fluorescens PG01; SG01, S. liquefaciens SG01; MA, matriconditioning dengan serbuk arang sekam; MG, matriconditioning dengan serbuk gergaji 
Tabel 4 Insidensi penyakit layu fusarium pada tomat pada perlakuan teknik invigorasi benih yang diintegrasikan dengan rizobakteri

\begin{tabular}{lc}
\hline Perlakuan benih & Insidensi penyakit (\%) \\
\hline Kontrol & $20.24 \mathrm{a}$ \\
Hidrasi & $20.24 \mathrm{a}$ \\
Fungisida & $17.86 \mathrm{ab}$ \\
Matrik Serbuk arang sekam (MA) & $11.90 \mathrm{a}-\mathrm{d}$ \\
Matrik Serbuk gergaji (MG) & $14.29 \mathrm{a}-\mathrm{c}$ \\
Biopriming BG25 & $4.76 \mathrm{f}$ \\
Biopriming PG01 & $7.14 \mathrm{c}-\mathrm{f}$ \\
Biopriming SG01 & $9.52 \mathrm{~b}-\mathrm{f}$ \\
Biopriming BG25 + PG01 & $10.71 \mathrm{~b}-\mathrm{e}$ \\
Biopriming BG25 + SG01 & $5.95 \mathrm{ef}$ \\
Biopriming PG01 + SG01 & $13.10 \mathrm{a}-\mathrm{d}$ \\
Biopriming BG25 + PG01 + SG01 & $7.14 \mathrm{c}-\mathrm{f}$ \\
Biomatrik BG25 + MA & $5.95 \mathrm{ef}$ \\
Biomatrik PG01 + MA & $9.52 \mathrm{~b}-\mathrm{f}$ \\
Biomatrik SG01 + MA & $13.10 \mathrm{a}-\mathrm{d}$ \\
Biomatrik BG25 + MG & $10.71 \mathrm{~b}-\mathrm{e}$ \\
Biomatrik PG01 + MG & $5.95 \mathrm{ef}$ \\
Biomatrik SG01 + MG & $10.71 \mathrm{~b}-\mathrm{e}$ \\
\hline
\end{tabular}

Angka-angka yang diikuti oleh huruf yang sama menunjukkan tidak berbeda nyata pada taraf uji DMRT $\alpha 5 \%$. BG25, B. polymixa BG25; PG01, P. fluorescens PG01; SG01, S. liquefaciens SG01; MA, matriconditioning dengan serbuk arang sekam; MG, matriconditioning dengan serbuk gergaji.

yang terbaik. B. polymixa dan P. fluorescens adalah kelompok rizobakteri pemacu pertumbuhan tanaman yang efektif meningkatkan pertumbuhan dan hasil tanaman. Peranan $B$. polymixa dan $P$. fluorescens sebagai pemacu pertumbuhan diduga berkaitan dengan kemampuanya melarutkan fosfat, memfiksasi nitrogen, memproduksi auksin (IAA) dan sitokinin (Sutariati et al. 2012).

Aplikasi seed matriconditioning sebagai media inokulasi rizobakteri pada benih juga memberikan peran positif yang tidak dapat diabaikan. Seed conditioning bertujuan untuk mempercepat dan menyeragamkan pertumbuhan serta meningkatkan persentase pemunculan kecambah dan bibit. Prinsipnya ialah memobilisasi sumber daya yang dimiliki benih (internal) ditambah sumberdaya dari luar (eksternal) untuk memaksimalkan perbaikan pertumbuhan dan hasil tanaman. Seed conditioning merupakan perbaikan fisiologis dan biokimiawi yang berhubungan dengan kecepatan dan keserempakan, perbaikan dan peningkatan potensi perkecambahan dalam benih selama penundaan perkecambahan oleh media potensial matrik rendah (matriconditioning) atau oleh media berpotensial osmotik rendah (priming atau osmoconditioning), dan terbukti efektif meningkatkan viabilitas dan vigor benih (Ilyas 2006). Penggunaan teknologi invigorasi benih ditambah rizobakteri juga mampu melindungi benih yang ditanam dari infeksi cendawan patogen tular benih dan tular tanah (Silva et al. 2004).

Selain berfungsi sebagai pemacu pertumbuhan, rizobakteri juga efektif mengendalikan penyakit layu fusarium pada tomat. Kemampuan bakteri rizosfer sebagai agens hayati patogen berhubungan dengan kemampuannya secara langsung memproduksi metabolit sekunder seperti siderofor, HCN, enzim ekstrasel dan senyawa antibiotik atau secara tidak langsung dengan menginduksi ketahanan tanaman terhadap infeksi patogen (Kazempour 2004; Kim et al. 2008). Indikator adanya induksi resistensi tanaman terhadap infeksi patogen yang disebabkan oleh perlakuan rizobakteri telah dilaporkan sebelumnya, antara lain terjadi 
peningkatan aktivitas enzim peroksidase, fenilalanin amonia-liase dan polifenol oksidase serta produksi senyawa fitoaleksin (Silva et al. 2004; Hoerussalam et al. 2013). Hasil penelitian ini juga menunjukkan bahwa penggunaan teknik invigorasi benih yang diintegrasikan dengan rizobakteri selain mampu memperbaiki pertumbuhan tanaman, juga mampu melindungi tanaman dari infeksi cendawan patogen bahkan lebih baik dibandingkan dengan penggunaan fungisida.

Penerapan rizobakteri dalam budi daya tanaman dapat digunakan sebagai teknologi alternatif yang berperan ganda sebagai pemacu pertumbuhan tanaman dan pengendali penyakit. Hasil penelitian membuktikan bahwa integrasi teknik biomatriconditioning arang sekam padi dengan rizobakteri dapat meningkatkan pertumbuhan dan hasil tanaman tomat, dan menurunkan insidensi penyakit layu fusarium yang merupakan salah satu penyakit penting pada tanaman tomat.

\section{DAFTAR PUSTAKA}

[BPS] Badan Pusat Statistik. 2004. Survei Pertanian: Produksi Tanaman Sayuran dan Buah-Buahan Indonesia. Jakarta (ID): Badan Pusat Statistik.

Guo JH, Hong YQ, Guo YH, Gong LY, Zhang LX, Sun PH. 2004. Plant growth promoting activities of rhizobacteria associates with tomato in semi-arid region. Biol Control. 29(1):66-73. DOI: http://dx.doi.org/1016/s 1049-9644(03)00124-5.

Hoerussalam, Purwantoro A, Khaeruni A. 2013. Induksi ketahanan tanaman jagung (Zea mays L.) terhadap penyakit bulai melalui seed treatment serta pewarisannya pada generasi S1. J Ilmu Pert. 16(2):42-59.

Ilyas S. 2006. Seed treatments using matriconditioning to improve vegetable seed quality. Bul Agron. 34(2):124-132.

Kazempour MN. 2004. Biological control of Rhizoctonia solani, the causal agent of rice sheath blight by antagonistics bacteria in greenhouse and field conditions. Plant Pathol J. 3(1):88-96.
Khaeruni A, Wahab A, Taufik M, dan Sutariati GAK. 2013. Keefektifan Waktu Aplikasi Formulasi Rizobakteri Indigenos untuk Mengendalikan Layu Fusarium dan Meningkatkan Hasil Tanaman Tomat di Tanah Ultisol. J Hort. 23(4):365-371.

Khaeruni A, Asniah, Taufik M, Sutariati GAK. 2014. Aplikasi formulasi rizobakteri untuk pengendalian penyakit busuk akar rhizoctonia dan peningkatan hasil kedelai di tanah ultisol. J Fitopatol Indones. 10(2): 37-44. DOI: http://dx.doi.org/10.14692/ jfi.10.2.37.

Kim YC, Jung H, Kim KY, Park SK. 2008. An effective biocontrol bioformulation against Phytophthora blight of pepper using growth mixtures of combined chitinolytic bacteria under different field conditions. Eur J Plant Pathol. 120:373-382. DOI: http://dx.doi. org/10.1007/s10658-007-9227-4.

Silva HSA, Romeiro RSR, Macagnan D, Vieira BAH, Pereira MCB, Mounteer A. 2004. Rhizobacterial induction of systemic resistance in tomato plants: nonspecific protection and increase in enzyme activities. Biol Control. 29(3):288-295. DOI: http://dx.doi.org/10.1016/S10499644(03)00163-4.

Sutariati GAK, Khaeruni A. 2013. Seed biomatriconditioning using rhizobacteria for growth promotion and increase the yield of sorghum (Sorghum bicolour (L.) Moench) on marginal soil. Agric Sci Res J. 3(3):85-92.

Sutariati GAK, Safuan LO, Wahab A. 2012 Karakter Fisiologis dan Kemangkusan Rizobakteri Indigenus Sulawesi Tenggara sebagai Pemacu Pertumbuhan Tanaman Cabai. J Hort. 22(1):57-64.

Sutariati GAK, Wahab A. 2011. Karakter fisiologi dan kemangkusan rizobakteri indigenus Sulawesi Tenggara sebagai pemacu pertumbuhan tanaman cabai. J Hort. 22(1):57-64.

Sutariati GAK, Widodo, Sudarsono, Ilyas S. 2006. Pengaruh perlakuan Plant Growth Promoting Rhizobacteria terhadap pertumbuhan bibit tanaman cabai. Bul Agron. 34(1):46-54. 